\title{
$3 D$ IMAGES OF LEAVES: A PHOTO SHOOT WE SHOULD ALL BE LOOKING AT
}

IN OUR MODERN AGE OF "PLANT BLINDNESS" - WHERE PEOPLE UNDERAPPRECIATE THE PLANTS AROUND US - PROFESSOR MARGARET BARBOUR AND HER PHD STUDENT, RICHARD HARWOOD, ARE IMAGING LEAVES IN THREE DIMENSIONS. NOT ONLY WILL THEIR FINDINGS FURTHER OUR UNDERSTANDING OF HOW LEAVES FUNCTION, THESE IMAGES COULD HELP US TO RECOGNISE JUST HOW VITAL PLANTS ARE TO LIFE ON EARTH

\section{IMAGINE THIS}

The first land plants appeared

approximately 470 million years ago. This was during what is known as the Ordovician period, when life was diversifying rapidly. While these plants were non-vascular (they didn't have water transport structures), they are thought to have eventually led to an ice age and a mass extinction, according to the New Scientist.

Plants absorb carbon dioxide and release oxygen through their leaves. Without photosynthesis we would suffocate from lack of oxygen and we would have very little - if anything - to eat. Plants also help clean water. This short video from the BBC explains just how important plants are:

https://tinyurl.com/y289w15o

\section{QUICK FACTS}

ORGANELLES are tiny structures inside cells that work together to perform specific tasks.

CHLOROPLASTS (shown right in green) are organelles found in green algae and plant cells. Their job is to help turn sunlight into food that can be used by the cell, through a process called photosynthesis.

\section{MITOCHONDRIA (shown right in} red) are organelles that exist in the cells of plants and animals. Often called the "powerhouses of the cell", their function is to break down sugars and create energycarrier molecules for the cell.
Plants could arguably be said to be the unsung champions of life as we know it. Rare is the day that we do not encounter a plant in some form or another, from walking by hedgerows on our way to school to sitting at the dinner table with the family to eat. Indeed, plants underpin all life on Earth, including humans. The air we breathe and the food we eat comes from plant life, and yet scientists still have a lot to learn about plants. Sciences, University of Sydney, Professor Margaret Barbour and her PhD student, Richard Harwood, are imaging leaves in three dimensions. By imaging leaves in this way, Margaret and Richard are hoping to develop our understanding of leaf function and answer questions that have eluded scientists so far.

HOW DOES THE 3D IMAGING OF LEAVES WORK?

Most of our knowledge of leaf anatomy and
Based at the School of Life and Environmental

how this links to leaf function comes from $2 \mathrm{D}$ cross-sections of leaves. However, the leaf interior is a complex 3D arrangement of cells and tissues that allow light capture and gas (oxygen and carbon dioxide) diffusion for photosynthesis, as well as regulation of water transport. Margaret and Richard have developed a microscopic technique that, for the first time, enables 3D imaging of leaf cells and their organelles, including chloroplasts and mitochondria.

WHAT TECHNOLOGY IS INVOLVED IN CREATING THE 3D IMAGES?

Margaret and Richard take a very small sample of a leaf, replacing all of the water in the leaf sample with a chemical solution called glutaraldehyde under a gentle vacuum to fix all the structures in place. They then use heavy metal staining to enhance the contrast between different structures, such as cell walls and chloroplast membranes, and to compare these with the large vacuole in the middle of the cells. The sample is then embedded in resin and trimmed to make sure they are imaging the correct part of the leaf.

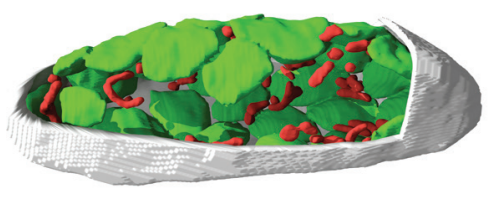

A 3D image of a chickpea mesophyll cell

VACUOLES are also organelles found in animal and plant cells. Filled with fluid, vacuoles are the space in the middle of the cell and have many important functions, including storing nutrients and waste products to help cells survive. There is usually one large vacuole in each plant cell.
"Imaging is carried out using a field emission scanning electron microscope that has an automatic microtome [a tool for cutting extremely thin slices]," explains Margaret. "An image of the surface of the sample is taken, then the microtome cuts a very thin slice off the top and another image is taken. This is repeated 800 times to build up a stack of images that can be analysed using $3 D$ reconstruction software."

DID THE 3D IMAGING TECHNOLOGY ALREADY EXIST?

The field emission scanning electron microscope has been widely used for animal samples like liver and kidney tissues. Plant tissue is harder to image because plant cell 



\section{ABOUT PLANT}

Plant science goes by many different names - botany, plant biology or phytology - but they all essentially mean the same thing, which is the science of plant life. It should be understood as a branch (no pun intended) of biology, which has evolved over time to become a broad, multidisciplinary subject involving a range of other areas of science and technology.

\section{HOW HAS PLANT SCIENCE}

EVOLVED OVER THE YEARS?

When people first began studying plants, their main concerns were describing what they looked like, where they grew, what they could be used for and how related they were to one another. Sometime during the $17^{\text {th }}$ century, however, scientists started to turn their investigations towards understanding how plants function - how they grow, how they sense and respond to their environment, their biochemical pathways and, more recently, the molecular genetics of plants. Today, all of these topics of interest fit within the broad area of plant physiology.
WHERE DID THE IDEA TO IMAGE LEAVES IN 3D STEM FROM?

When scientists first saw the structure of a leaf through microscopes, they recognised that there was a complicated 3D structure and organisation within leaves. They built beautiful wax models of the inside of leaves to represent what they saw and teach botany students about plants. You can still see some very early wax models of leaves at the Orta Botanico di Pisa botanical garden.

"Our team has wanted to image the inside of leaves in 3D ever since we saw 3D X-ray computed tomography images of soil and roots in the mid-2000's," explains Margaret. "We recognised just how powerful 3D images would be to advance our understanding of leaf function."

THE ROYAL SOCIETY OF BIOLOGY SAYS THERE IS A SHORTAGE OF PLANT SCIENTISTS IN THE UK. CAN THE SAME BE SAID FOR AUSTRALIA? Yes. There is a shortage of plant scientists in the agriculture industry, in biosecurity and in biodiversity conservation in Australia. Problems associated with global warming and climate change will only increase the need for plant scientists in Australia and around the world, so the field is ripe for students who are interested in developing a career in the field.

THE SOCIETY ALSO CLAIMS THAT PLANT SCIENTISTS ARE RESPONDING TO SOME OF THE MOST CRITICAL CHALLENGES OF THE $21^{\text {ST }}$ CENTURY. WHAT ARE THESE CHALLENGES? Some the most pressing issues facing humanity require an understanding of how plants function, including understanding and responding to climate change, biodiversity conservation, addressing food and nutrition security, and planning our cities for the future. In fact, of the 17 UN sustainable development goals (SDGs), plant science contributes to seven of them. The contribution that plant scientists can make to an ever-changing world can hardly be overstated.

\section{OPPORTUNITIES IN PLANT SGIENGE}

- There are almost unlimited career opportunities in the field of plant science. Options include agronomist, biochemist, entomologist, horticulturist, soil scientist and toxicologist, forestry researcher, gardening show TV host - and options will only increase in the future! Just take a look at CropLife International.

- According to PayScale, the average salary for a botanist in Australia is AU $\$ 68,837$

- The Chartered Institute of Horticulture has loads of information about how you can make a difference by studying the field of plant science and technology

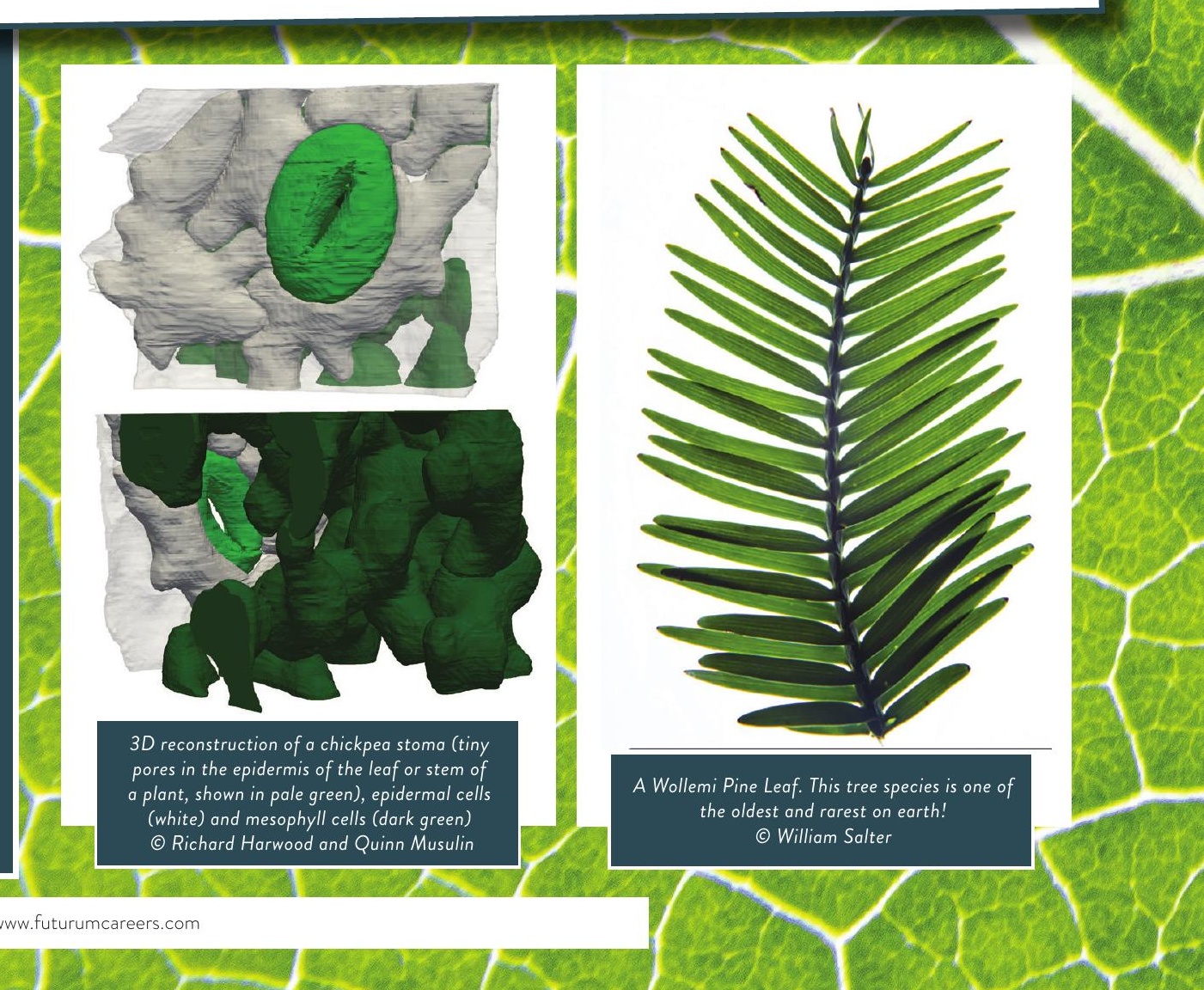


